\title{
Modelling of the information system for monitoring the activities of a travel agency
}

\author{
Lidija Paunović $^{1 *}$, Alempije Veljović ${ }^{1}$ \\ ${ }^{1}$ University of Kragujevac, Faculty of Tehnical Sciences in Čačak
}

\begin{abstract}
The field of research of this paper is focused on modelling the information system, in order to improve the operation of travel agencies. By combining modern methods, information technologies and their practical applications, systems have been developed to facilitate access to relevant information as well as to monitor the business activities of travel agencies. The research subject of this paper refers to the improvement of the business of travel agencies through the introduction of an information system into the processes of agency business. The goal of the research is to design and develop a universal information system that will provide a more efficient and effective business for travel agencies in order to respond better to the demands of the users (both internal and external). The development of CASE (Computer Aided Software Engineering) tools i.e. BPwin, (Bussines Process for Windows) for business process modelling (the IDEF0 - Integrated Computer Aided Manufacturing DEFinition for Function Modelling standard) and Erwin (Entity Relationships for Windows) for data modelling (the IDEF1X - Integration DEFinition for information modelling standard), have enabled the modelling of the information system for monitoring the agency business. The research was carried out through the realization of functional, informational and applied modelling.
\end{abstract}

Keywords: modelling, travel agency, information system, IDEF0, IDEF1X JEL classification: $\mathrm{O} 31, \mathrm{O} 32$

\section{Modeliranje informacionog sistema za praćenje poslovanja turističke agencije}

Sažetak: Područje istraživanja ovog rada usmereno je ka modeliranju informacionog sistema, radi unapređenja poslovanja turističkih agencija. Kombinacijom savremenih metoda, informacionih tehnologija i njihove praktične primene, razvijeni su sistemi koji olakšavaju pristup relevantnim informacijama kao i praćenje poslovnih aktivnosti turističkih agencija. Predmet istraživanja rada, odnosi se na unapređenje poslovanja turističkih agencija kroz uvođenje informacionog sistema u procese agencijskog poslovanja. Cilj istraživanja jeste projektovanje i razvoj univerzalnog informacionog sistema koji će obezbediti efikasnije i efektivnije poslovanje turističkih agencija, kako bi što bolje odgovorile na zahteve korisnika (kako internih tako i eksternih). Razvoj CASE (Computer Aided Software Engineering) alata tj. BPwin, (Bussines Process for Windows) za modeliranje poslovnih procesa (standard IDEF0 - Integrated Computer Aided Manufacturing DEFinition for Function Modeling) i ERwin (Entity Relationships for Windows) za modeliranje podataka (standard IDEF1X - Integration DEFinition for information modeling), omogućio je modeliranje informacionog sistema za praćenje agencijskog poslovanja. Istraživanje je sprovedeno kroz realizaciju funkcionalnog, informacionog i aplikativnog modeliranja.

* lidija.paunovic@ @tn.kg.ac.rs 
Ključne reči: modeliranje, turistička agencija, informacioni sistem, IDEF0, IDEF1X JEL klasifikacija: O31, O32

\section{Introduction}

The development of technology causes changes that provide opportunities for more efficient and effective operation in all areas of business.

As the modelling of business processes and data is of great importance for the reengineering of performance of every business system, modeling of the information system is also applicable in the field of business of travel agencies (Milentijević et al., 2013; Mosleh \& Nosratabadi, 2015). Modelling of the information system establishes simpler processes of communication and collaboration between both employees within the organization and employees with business clients.

Modelling of the information system enables instant access to different information, dynamics and real-time information provision, higher level of communication and cooperation between employees, as well as between employees and clients, personalized interaction between users and overcoming time and space barriers (Paunović et al., 2011).

Baseline studies are based on the use of CASE tools in business systems in general (Montini et al., 2014; Harmon, 2015; Skersys et al., 2015), on the basis of what has been observed as the need for implementation in the field of hotel business and tourism. (Maksimović et al., 2017).

Apart from the unique model of the information system proposed in this paper, with the help of the mentioned tools, it is possible to model the system according to the specific user requirements (Truong et al., 2014), in accordance with legal requirements. By introducing business intelligence into the travel agency's business system, it enables consistent delivery of information, decision making based on facts, improved communication, time and money saving. Such an information system enables successful integration of information into the agency's business, ensuring competitiveness as an imperative factor for the prosperity in the market.

\section{Research methodology}

The research methodology refers to three methodologies carried out in the paper itself and they are:

- the functional modelling methodology, using the IDEF0 standard,

- the information modelling methodology, using the IDEF1X standard,

- the application modelling methodology.

The functional modelling methodology enables the decomposition of business functions and the planning of the necessary resources for the realization of functions (Havey, 2005). The IDEF0 standard has been developed to present activities or processes that are conducted in an organized and standardized way (Waissi et al., 2015). The IDEF0 standard can be defined as a set of activities that can transform certain inputs, by means of a certain mechanism, subject to certain controls, into outputs. These inputs, outputs, controls and mechanisms are used to model relationships between different activities (FIPS, 1993; Cheol-Han, 2003).

The information modeling methodology is presented using the IDEF1X standard. The IDEF1X standard (FIPS, 1993) represents a technique of modeling of semantic data that support the development of conceptual schemes. It provides a formal overview of the entities, attributes, and relationships between the entities. Every attribute of the IDEF1X 
model can only have one owner. An important term in the IDEF1X standard refers to the use of entity keys. The entity key is the smallest set of entity attributes necessary for uniquely identifying entity instances. Each entity must have at least one key (Cheol-Han et al., 2003).

The application modelling methodology is used for the rendering of the data model into the selected database management system (Karpuk \& Krasnoproshin, 2017). The selected system implies the information infrastructure within which the application solution will be implemented.

\section{Research results and discussion}

The applied modelling methodology was used, with the help of CASE tool BPwin, to conduct business process modelling. The modelling of business processes was realized through the following three types of diagrams:

- Context diagram for the monitoring of agency business,

- Activities tree for the monitoring of agency business,

- Decomposition diagram for the monitoring of agency business.

Context diagram for the monitoring of agency business is shown in Figure 1 (Veljović et al., 2009). It implies the highest level of abstraction. The inputs, outputs, mechanisms and controls that represent the boundaries of the model are defined within the diagram.

Figure 1: Context diagram for the monitoring of agency business

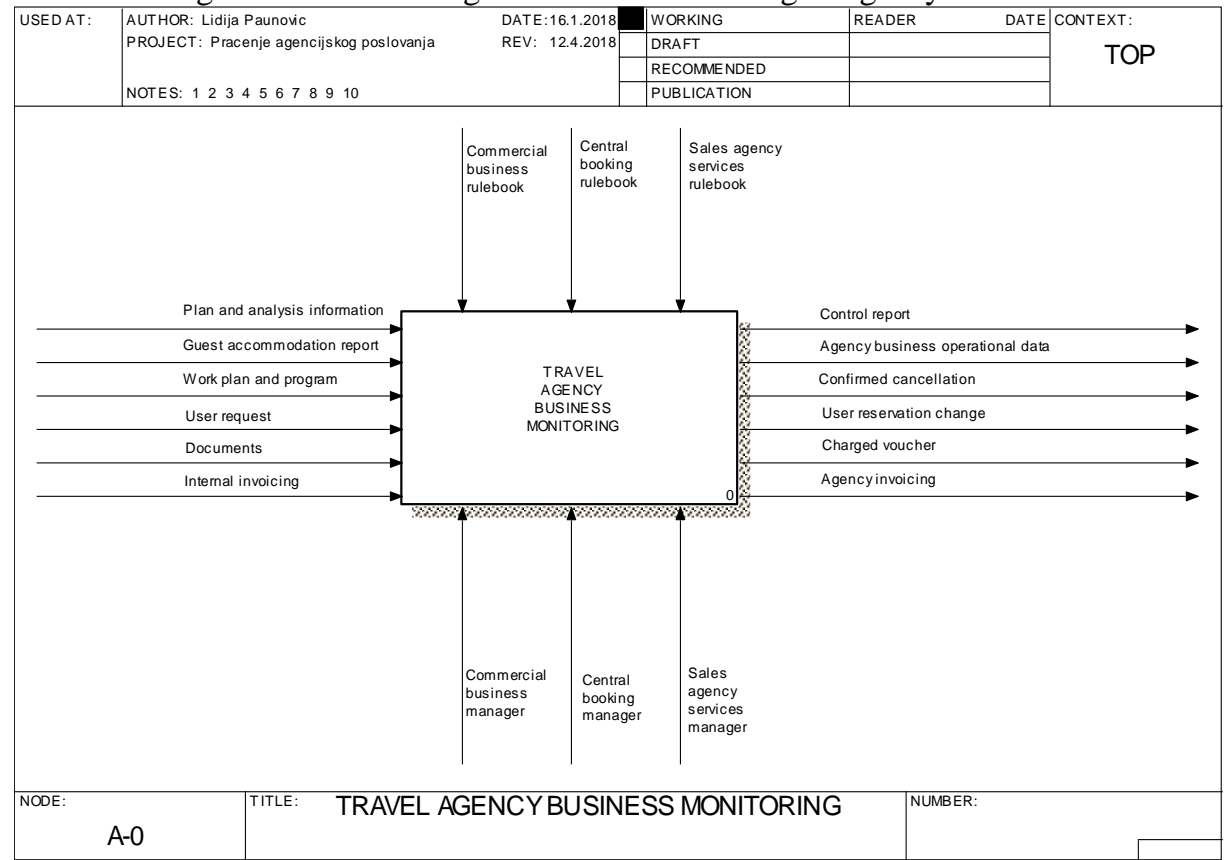

Vertical connections between the activities defined on the basis of the set model boundaries are shown in Figure 2, within the activities tree for the monitoring of agency business. Starting activity The monitoring of agency business is explained by subordinate activities. The figure shows the decomposition of the starting activity up to the third level. 
Figure 2: Activities tree for the monitoring of agency business

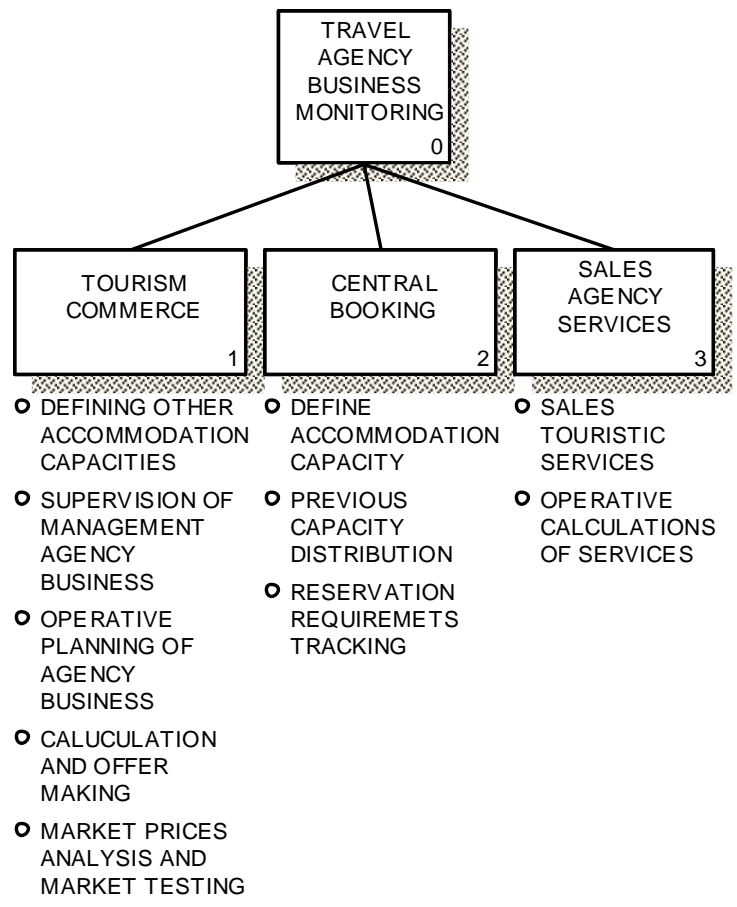

After vertical connections have been established within the framework of defining the activities tree, horizontal links between activities of the same level have been established. Horizontal connections are shown in Figure 3 (Veljović et al., 2009), within the decomposition diagram. Decomposition diagram for the monitoring of agency business allows the connection of appropriate information defined within the activities tree.

Figure 3: Decomposition diagram for the monitoring of agency business

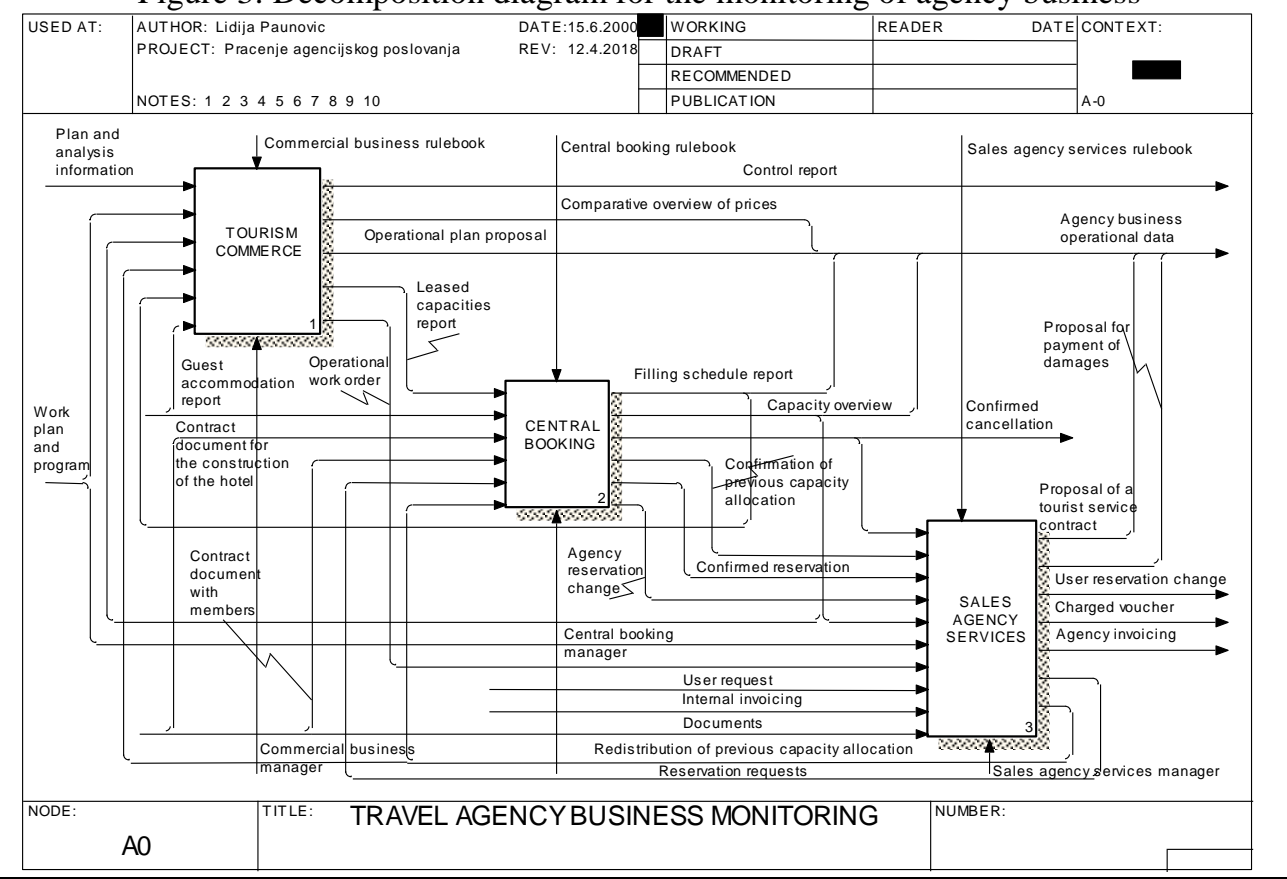


For the realization of information modelling a CASE tool ERwin was used, with the help of which data modelling was performed.

Data modeling has been defined through three models:

- Conceptual data model for the monitoring of agency business,

- Logical data model for the monitoring of agency business,

- Physical data model for the monitoring of agency business.

Conceptual data model (CDM - conceptual data model) covers only specific business needs that are presented by process analysis. The conceptual model defines entities and relationships between them. At this level, the highest level of links between entities has been identified. Figure 4 shows the conceptual data model for the monitoring of agency business.

Figure 4: Conceptual data model for the monitoring of agency business

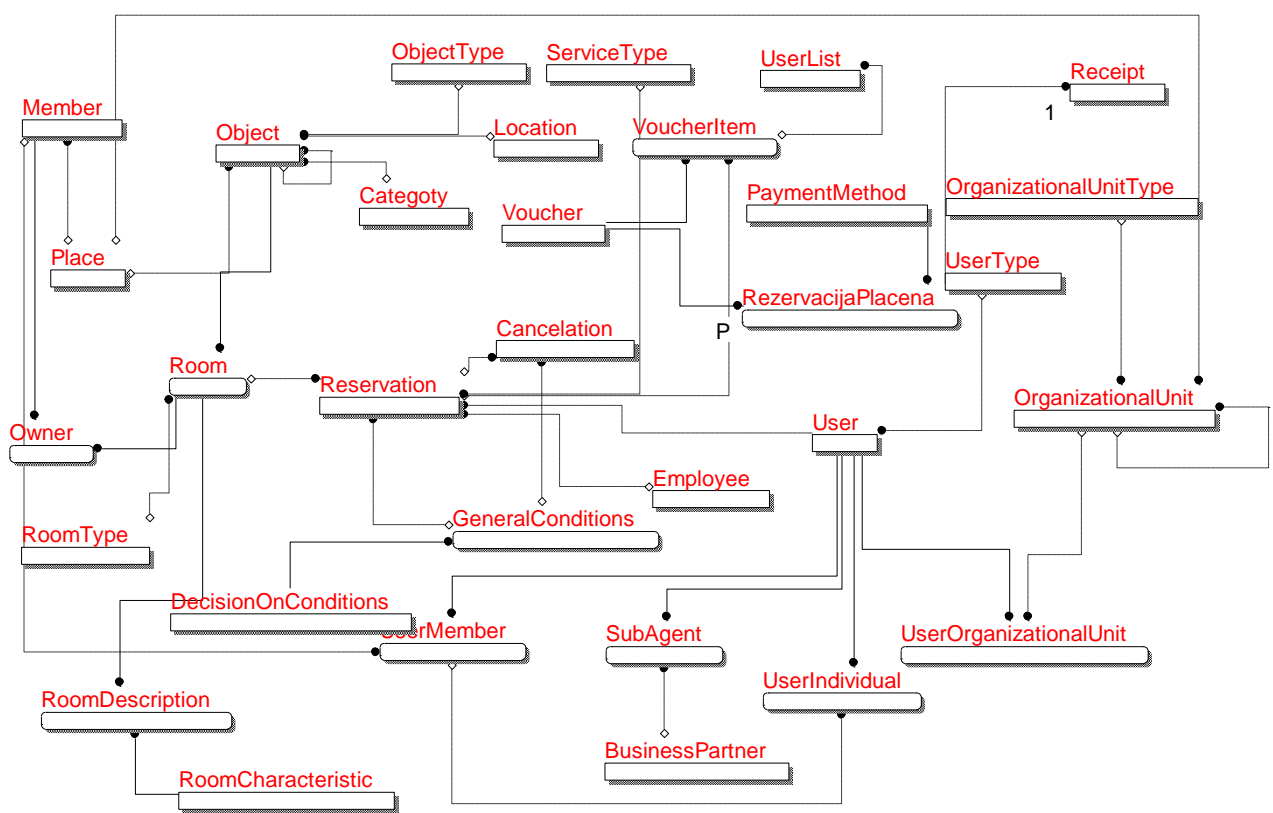

Logical data model (LDM - logical data model) is shown in Figure 5. It defines a detailed overview of the observed business. It applies purely theoretical settings regardless of the physical-level implementation. The logical model is based on the conceptual model on the one hand and pre-set processes on the other. Within the logical model, the data is described in more detail, regardless of the method of implementation in the database. In this regard, the logical model includes the entities and links between them, the entity attributes, the primary key for each entity as well as the external keys. The normalization process is included within the logical model. 
Figure 5: Logical data model for the monitoring of agency business

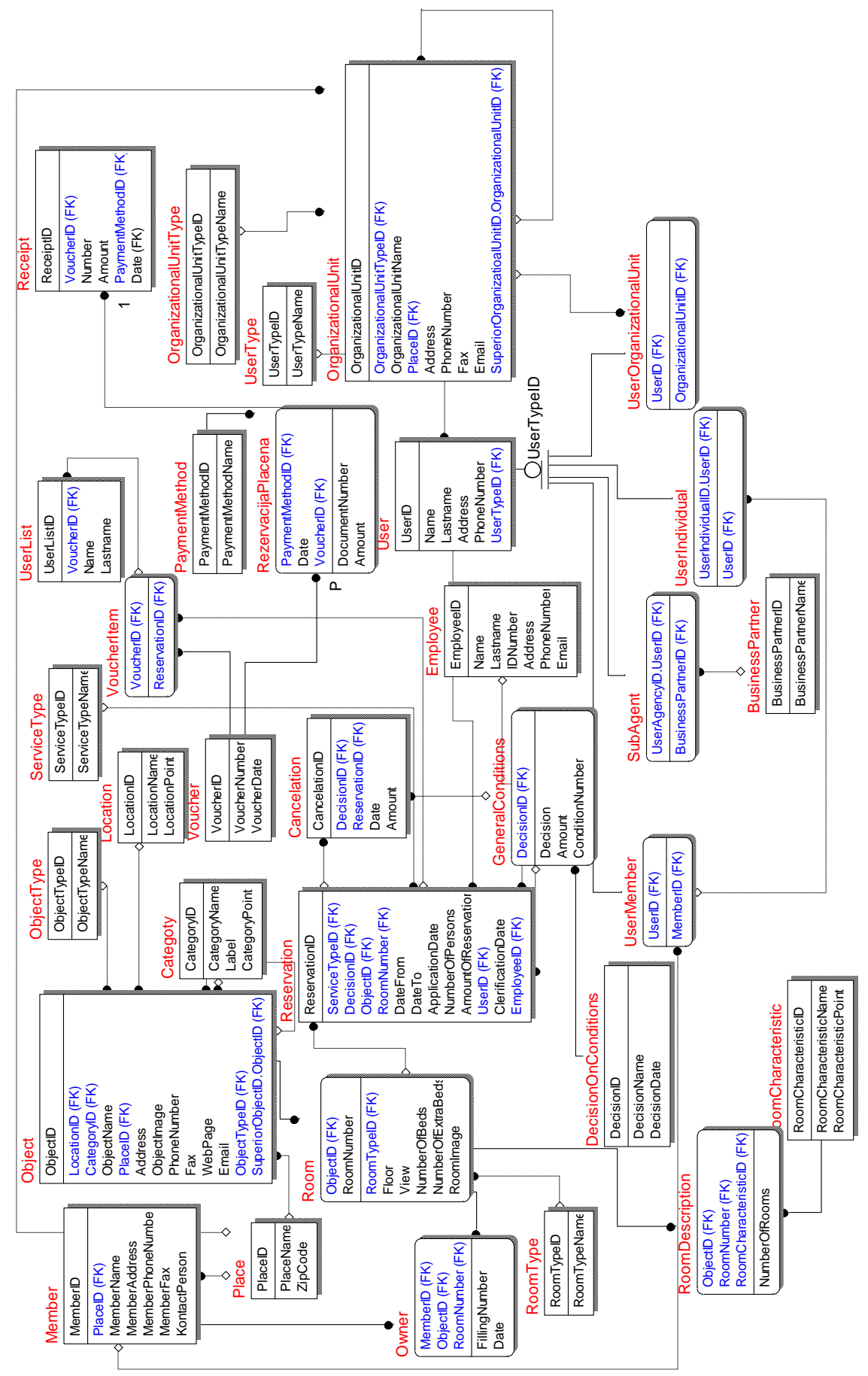

After a defined logical model that encompasses the entities, their attributes and connections, the physical data model is defined (PDM - physical data model) and shown in Figure 6. The physical model is a detailed description of the concept as well as a technical solution, which is why it is adapted to the architecture in which the solution will be implemented. The physical model includes the specification of all tables and columns as well as external keys. 
Within this model, denormalization is performed based on user requests. In order to design a projected model that will be implemented in the database, the transition of the entities into tables, the connection to external keys and attributes in the columns is performed.

Figure 6: Physical data model for the monitoring of agency business

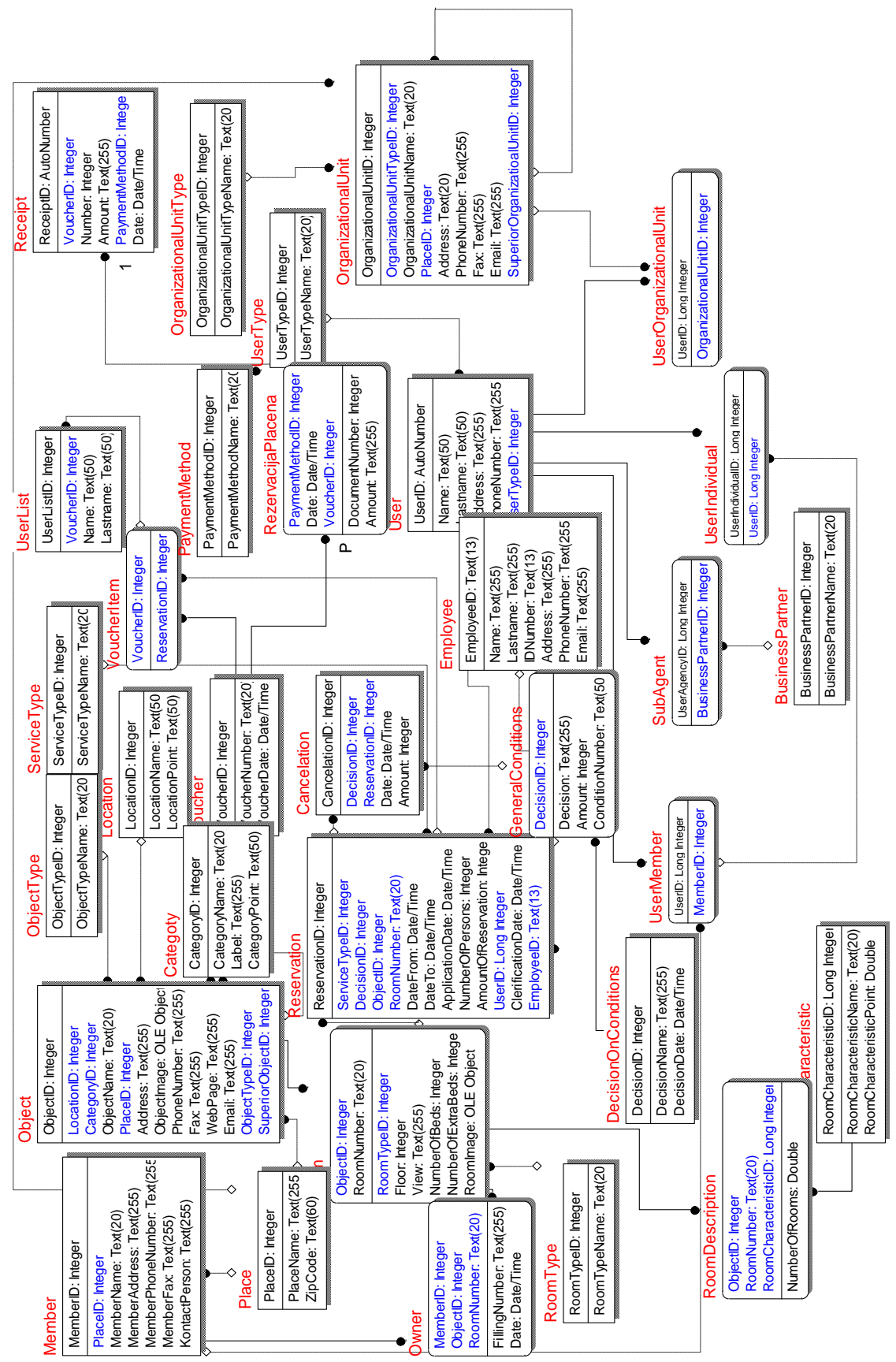

Application modelling is considered from the point of view of the chosen database management system. Figure 7 the shows display forms of the Travel Agency's business. As a software solution for creating a database and implementing screen formats MS Access was selected. 
Figure 7: Display forms of the Travel Agency's business

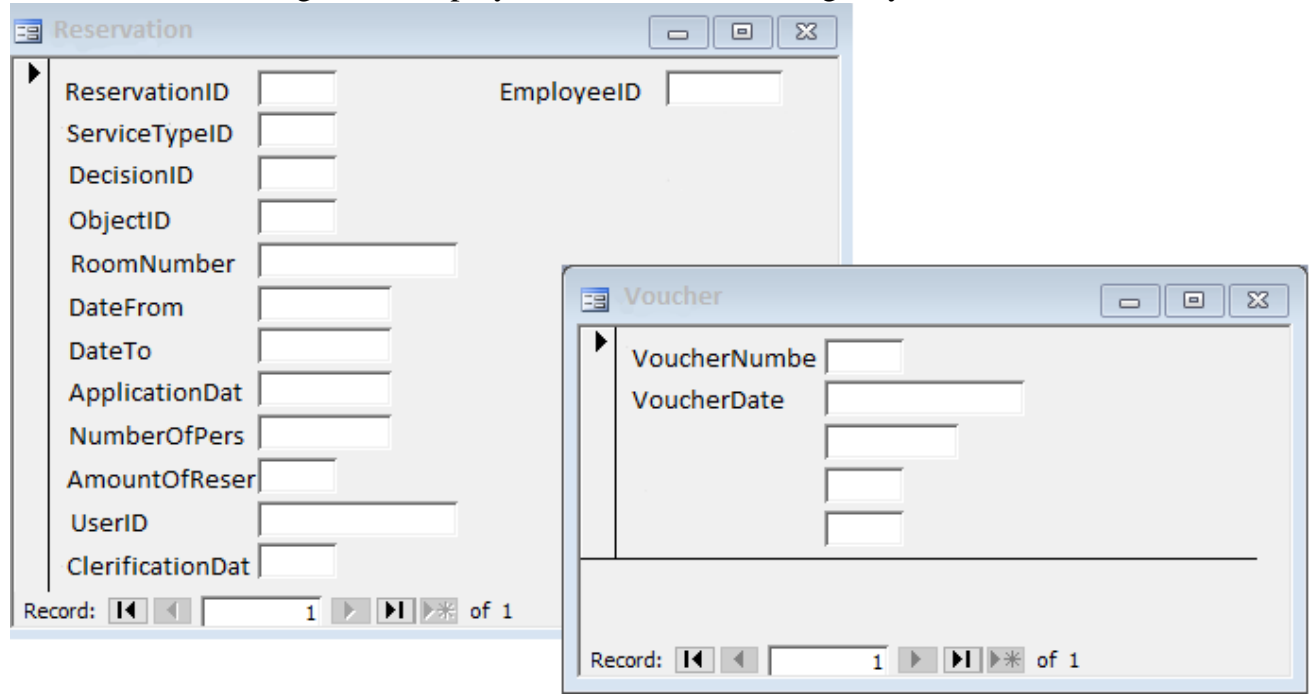

\section{Conclusion}

The information system for monitoring the business of a travel agency was modelled by the conducted research. For the observed system, the modelling of business processes has been proposed and executed through the defined depth and width of the system (vertical and horizontal connections). A conceptual data model that addresses specific business needs is defined. Based on the aforementioned modelling, a logical model has been established, which shows in more detail the entities and relationships between them, after which a physical model is implemented, which describes in detail the stated concept. Database generation, data entry as well as prototype-made client side have been executed. Implementation of the database and the display form itself is shown as the last item within the modelling process itself.

In this way, the implementation of a software solution according to user requirements is enabled, based on the experience gained through the operation of the real system. Optimized access to data was achieved through the access to a single database.

Modelling of the information system allows:

- optimization of business processes,

- improvement of relations with the target public,

- improvement of other business support services.

The directions of future research are reflected in the possibility of further development and improvement of the system through the implementation of the business intelligence model. Using business intelligence tools, the collected information and data are transformed into the knowledge that is used in the business decision making process, thus completing the agency's management system.

\section{References}

1. Cheol-Han, K., Weston, R. H., Hodgson, A. \& Kyung-Huy L. (2003). The complementary use of IDEF and UML modelling approaches. Computers in Industry, 20(1), 35-56. https://doi.org/10.1016/S0166-3615(02)00145-8 

Hotel and Tourism Management, 2018, Vol. 6, No. 1: 31-39.

2. FIPS (1993). Draft Federal Information Processing Standards Publication 183. Retrieved March 27, 2018 from http://www.idef.com/wpcontent/uploads/2016/02/idef0.pdf

3. Harmon, P. (2015). The Scope and Evolution of Business Process Management. In J. vom Brocke \& M. Rosemann (Eds.), Handbook on Business Process Management 1. International Handbooks on Information Systems (pp. 37-80). Berlin, Heidelberg: Springer. https://doi.org/10.1007/978-3-642-45100-3_3

4. Havey, M. (2005). Essential Business Process Modeling. O'Reilly Media.

5. Karpuk, A. A. \& Krasnoproshin, V. V. (2017). Methodology of data domain description for databases design in complex systems. Web of scholar, 4(13), 11-20.

6. Maksimović, G., Sekulić, D., Petrović, A. \& Dragičević, D. (2017). Savremeni trendovi i nove strategije konkurentnosti u hotelijerstvu [Contemporary trends and new competitiveness strategies in hotel industry]. Menadžment $u$ hotelijerstvu $i$ turizmu, 5(2), 27-35.

7. Milentijević, D., Veljović, A. \& Paunović L. (2013). Poslovni procesi softverske platforme turistićke agencije [Business processes of tourist agency software platform]. Sym-Op-Is 2013 XL Simpozijum o operacionim istraživanjima, (pp. 75-80), Zlatibor.

8. Montini, D. A., Matuck, G. R., Da Cunha, A. M., Vieira-Dias, L. A. \& Isaac, M. J. (2014). BPM Model of GQIMP for ISO 9001:2008 Supported by CASE Tools. 11th International Conference on Information Technology: New Generations (pp. 15-20). Las Vegas, NV, USA: IEEE.

9. Mosleh, A. \& Nosratabadi, S. (2015). Technology-based Value Creation Processes in Tourism Agencies' Business Model. Management and Administrative Sciences, 4(2), 336-348.

10. Paunović, L., Stokić, A., Veljović, A. \& Radenković B. (2011). Razvoj informacionog sistema u funkciji upravljanja naučno-istraživačkim projektom [Developement of an information system for recording project managemnt research]. Nacionalna konferencija sa međunarodnim učešćem Reinženjering poslovnih procesa u obrazovanju 2011, (pp. 271-277), Čačak: Fakultet tehničkih nauka u Čačku Univerziteta u Kragujevcu.

11. Skersys, T., Pavalkis, S. \& Nemuraite, L. (2015). Implementing Semantically Rich Business Vocabularies in CASE Tools*. In T. E. Simos \& C. Tsitouras (Eds.), AIP Conference Proceedings, 1648(1), (pp. 310002-1-310002-4).

12. Truong, Y., Klink, R. R., Fort-Rioche, L. \& Athaide, G. A. (2014). Consumer Response to Product Form in Technology-Based Industries. Journal of Product Innovation Management, 31(4), 867-876. https://doi.org/10.1111/jpim.12128

13. Veljović, A., Vulović, R. \& Damnjanović A. (2009). Informaciono komunikacione tehnologije u menadžmentu [Information comunication technologies in management]. Čačak.

14. Waissi, G. R., Demir, M., Humble, J. E. \& Lev, B. (2015). Automation of strategy using IDEF0 - A proof of concept". Operations Research Perspectives, 2, 106-113. https://doi.org/10.1016/j.orp.2015.05.001 